\title{
Risk Factor of Human Immunodeficiency virus Encephalopathy in Children
}

\author{
Mia Milanti Dewi*, Anggraini Alam, Nelly Amalia Risan \\ Department of Child Health, Universitas Padjadjaran, Bandung, Indonesia \\ *Corresponding author: miamilanti@gmail.com
}

Received December 12, 2018; Revised January 16, 2019; Accepted February 19, 2019

\begin{abstract}
HIV-1 viral infections have been found worldwide, including Indonesia. This HIV-1 virus may affect in every group of ages and spread throughout the organs even the central nervous system. The most common complication in central nervous system is HIV encephalopathy (HIVE). HIVE is frequently unrecognized by clinicians. Symptoms of HIVE were included such as growth defect, microcephaly, and symmetrical motoric deficit that occurs for more than 2 months. The aim of this study is to find out the risk factor of HIVE among children in Teratai Clinic, Dr. Hasan Sadikin General Hospital Bandung. This was a cross sectional study conducted in Teratai Clinic, Dr. Hasan Sadikin General Hospital Bandung. All patients fulfilled inclusion criteria underwent anthropometric measurement, anamnesis, and neurologic examination. Analisis data using multivariate logistic regression. Data were processed by SPSS 20. During period of study, 37 (44\%) of pediatric patients with HIV were found suffered from HIVE, with mean of age of 71 months (20-153). Most of the patients were delivered spontaneously, breastfed, and living outside Bandung. Significant risk factor of HIVE incidence were age on diagnosis establishment ( $p=0,045,95 \%$ CI: $1,02-6,69)$ and duration of treatment ( $p=0,006,95 \%$ CI: 1$)$. Age on diagnosis that established $\leq 2$ years may contribute in HIVE risk factors. Antiretroviral (ARV) treatment $>5$ years may reduce risk of HIVE. Duration of treatment was more significant in decreasing risk of HIVE compared with age in diagnosis established. It was concluded that HIV prevalence in this study was $44 \%$. Age $\leq 2$ years old when diagnosed as HIV and duration ARV > 5 years are the significant risk factor on HIVE.
\end{abstract}

Keywords: encephalopathy, microcephaly, HIV, HIVE, Risk Factors

Cite This Article: Mia Milanti Dewi, Anggraini Alam, and Nelly Amalia Risan, "Risk Factor of Human Immunodeficiency virus Encephalopathy in Children.” American Journal of Clinical Medicine Research, vol. 7, no. 1 (2019): 18-25. doi: 10.12691/ajcmr-7-1-4.

\section{Introduction}

Human Immunodeficiency Virus (HIV) infection is caused by HIV type 1. [1,2] This subgroup of retrovirus is able to cause life threathening disease in its host. HIV infection is reported to be rising in recent years. Based on World Health Organization (WHO), there are 2,1 million new cases of HIV globally until the end of 2015 with 150.000 cases are in children with age less than 15 years old. [3,4] There are 36,7 millions people infected HIV worldwide, however only 17 millions whom received antiretroviral (ARV) by the end of 2015. [3,4,5] In pediatric population, HIV is reported around 3,3 millions worldwide with most of them (2,9 millions) live in Africa. [6] Since 1981, there are more than 20 millions children and adult have died due to AIDS (Acquired Immunodeficiency Diseases Syndrome) [1].

Prevalence of HIV is also rising in recent years. [5,6] Incidence of HIV increases 3 times from 2009 until 2014. [6] There are 30.935 new cases of HIV in 2015 which is lower than previous year. [5] By the end of 2015, there are 3.741 new cases of HIV in West Java. [5]
Based on Ministry of Health of the Republic of Indonesia, transmission risk perinatally is around 4\%. [5] Proportion of children with HIV infection based on age are reported as follow $<1$ year $(0,3 \%), 1-4$ year $(1,9 \%)$, 5 - 14 year (1,2\%), 15 - 19 year (2,9\%). [5] Despite relatively high incidence of HIV in pediatric population, mortality rate caused by AIDS in Indonesia is decreasing since 2004. Between 2014 and 2015, the Case Fatality Rate (CFR) in Indonesia decreases from $1,62 \%$ to $0,95 \%$. [5]

HIV infection can occur in adult and children with transmission through blood, semen, vaginal secret or perinatal. $[1,2,7,8,9]$ The risk of vertical HIV transmission in untreated pregnant woman is reported around 20-45\%. [1] Since 2004, Prevention of Mother to Child Transmission (PMTCT) has been carried out in Indonesia however this program lacks of HIV screening as part of antenatal care. [6] PMTCT programs are including providing ARV to pregnant infected woman, caesarean section delivery, formula milk and ARV prophylaxis for the offspring. [2] There are several methods reported to be effective in decreasing HIV infection in children despite persistent high prevalence HIV in children. [1-6] If all PMTCT programs were implemented, the risk of vertical 
HIV transmission could decrease to less than 2\%. [2] With the complete implementation, a study in Thailand reported the incidence of HIV in children decreased to less than $1 \%$. [10]

Based on age group, proportion of HIV infection in children with age less than 1 year in 2015 is reported to be 0,3\%. [5] Majority transmission of HIV cases in children occured through vertical transmission. [1-10] Recognition of HIV clinical symptoms in high risk women is really important in reducing HIV transimission to children. [6] In 2015, Rahmalia etc. [6] conducted cohort research in pregnant women with HIV at Dr. Hasan Sadikin General Hospital Bandung. However there was no data regarding HIV status of the offsprings. That study reported there were 79 children with positive HIV (mean age 3.1 years). [6]

HIV infection may cause disorder of many organs including central nervous system. [1,2,7,11,12] HIV infection of central nervous system can occur since age of 6 days. [13] Neurological manifestation in children is different to adult. [14] Neurological manifestations occur in around $50-60 \%$ of children who have not been treated with ARV. [11] These manifestation can be caused by HIV infection directly, oppurtunistic infection, malignancy, neurotoxic effect of ARV or other systemic complication. $[1,12,15]$ The most common central nervous system manifestation in children is HIV encephalopathy (HIVE) $[7,8,16,17]$.

According to Center of Disease Control (CDC), HIV is defined as at least 1 criterion (failure of maintenance or loss of developmental milestones or intellectual disability, impaired brain growth or presence of acquired microcephalus, symmetrical motoric deficit characterized by paresis, presence of pathological reflex, ataxia and/or disturbance in walking) which occurs at least for 2 months [1,6-20].

HIVE is often either unrecognized or delayed in diagnosis. [18] There are several studies about HIVE in children especially in sub Saharan countries. Prevalence of HIVE is ranging from $30-60 \%$ with latent phase period ranging from 2 months to 5 years or even manifesting after 10 years. [1,8,17]

Studies reported varying clinical manifestations of HIVE. A study from South Africa reported abnormal muscle tone and pathological gait, delayed motoric developmental (80\%), speaking retardation (75\%). [8,9] Donald KA etc. [11] found most of children with HIVE experienced developmental delays and difficulties in school. Motoric developmental delay is the first sign of HIVE in children. There are also several studies regarding HIVE in Asia and developing countries. In Malaysia, Hamid etc. [20] reported prevalence of HIVE was 18,2\%. A research in Jamaica found 23,3\% of children had HIVE with varying manifestation from developmental delay, hyperreflexia, spastic and microcephalus.

Neurological examination and neurocognitive function can predict progressivity of HIV. [16,21,22] There are several conditions related to HIVE that have been studied. Risk factor of HIVE is related to maternal and children immunity, viral load in cerebrospinal fluid and plasma, high circulating monocyte, time of infection, transmission route and early initial therapy. [8] Hamid etc. [20] reported CD4 count and percentage is associated with
HIVE. However that study found viral load is not significantly associated with HIVE. Several studies which examined intelligence found that there was intellectual disability in HIVE patients, while another studies reported different results. [20,22,23,24] Van rie etc. [25] found risk factor of high HIVE prevalence and severe central nervous system manifestation are including maternal and children immunity, high viral load in cerebrospinal fluid, time of infection, transmission route and ARV therapy. High risk of HIVE was found in maternal with high CD4 count and viral load during childbirth [25].

Administration of ARV therapy can reduce incidence of HIVE at perinatal or improve existing HIVE. [1-11,17,18] Outcome of HIVE patient will be better if the ARV is given as soon as possible. [13] However ARV administration for children with HIVE in South Africa is not well covered or delayed. [7] For about 32\% and 40\% children with HIVE are not given ARV in 2011 and 2014. [7] Administration of ARV in first month of life can protect children from HIV progressivity and improve neurodevelopmental outcome. [7] A study in USA found ARV administration resulted in decrease of HIVE from $35-50 \%$ to less than $2 \%$. [9] Short term (6 months) ARV may not decrease neurological or neurocognitive disorder. There is possibility of deterioration in early phase of therapy. [16] HIV stadium and viral load are reported as HIVE risk factor. [26]

Clinical manifestation of HIVE is ranging from mild to severe, clinician should be able to recognize HIVE as early as possible. Prevalence of HIVE in low to middle income countries are scarce with different results. [9] Early detection and appropriate management of HIVE can improve quality of life in children with HIV.

\section{Method}

This was a cross-sectional study. The research subjects were children diagnosed with HIV in Teratai Clinic, Dr. Hasan Sadikin General Hospital Bandung. Written consent were obtained from parents/guardian from all participants.

\subsection{Inclusion Criteria}

1. Diagnosed HIV infection by pediatrician with subspecialty in infection and tropical diseases.

2. Have been received ARV therapy

\subsection{Exclusion Criteria}

1. Presence of risk factor for developmental disorder (severe asphyxia, bilirubin encephalopathy, prematurity, neonatal seizure)

2. Multiple congenital anomaly

Data collection process underwent in Dr. Hasan Sadikin General Hospital Bandung. The participants were children diagnosed HIV infection and have been receiving ARV therapy. Parents/guardian of all subjects were interviewed, while the children were examined for anthropometric status, head circumference, and neurological status. Developmental delay was traced based on history examination to the parent or guardian of the children. 


\section{Results}

Until the early of 2017, there were 195 children diagnosed as HIV in Teratai Clinic, Dr. Hasan Sadikin General Hospital Bandung. Out of 195 children, 55 patients were drop-out from the treatment, 6 patients were transffered to another hospital and 10 patients died thus only 124 subjects were available to be research subject. Of 124 patients, 84 subjects participated in this study.

\subsection{Subject Characteristics}

The mean age of all subjects was 7,5 year (range 2 months - 15,8 year) with equal proportion between male and female. Majority of the subject $(51,1 \%)$ lived in Bandung.

In this study, 37 (44\%) subjects had HIVE, while 47 (56\%) subject had not HIVE (NHIVE). Furthermore, characteristics of both group are shown in Table 1.

\begin{tabular}{|c|c|}
\hline & $\begin{array}{c}\text { Total } \\
\mathrm{n}=\mathbf{8 4}\end{array}$ \\
\hline Age (month), median (min-max) & $85(2-190)$ \\
\hline \multicolumn{2}{|l|}{ Age Category, n (\%) } \\
\hline - <1 year & $1(1,2)$ \\
\hline - 1-3 year & $7(8,3)$ \\
\hline - 3-6 year & $26(31,0)$ \\
\hline - 6-11 year & $32(38,1)$ \\
\hline - 11-13 year & $9(10,7)$ \\
\hline - 14-17 year & $9(10,7)$ \\
\hline \multicolumn{2}{|l|}{ Sex, n (\%) } \\
\hline - Male & $44(52,4)$ \\
\hline - Female & $40(47,6)$ \\
\hline \multicolumn{2}{|l|}{ Level of Education, n (\%) } \\
\hline - None & $27(32,2)$ \\
\hline - Preschool & $16(19,0)$ \\
\hline - Special School & $1(1,2)$ \\
\hline - Elementary School & $33(39,3)$ \\
\hline - Junior High School & $7(8,3)$ \\
\hline \multicolumn{2}{|l|}{ Control, n (\%) } \\
\hline - Midwife & $69(82,2)$ \\
\hline - General Physician & $7(8,3)$ \\
\hline - Obstetrician & $8(9,5)$ \\
\hline \multicolumn{2}{|l|}{ ARV During Pregnancy, n (\%) } \\
\hline - No & $80(95,2)$ \\
\hline - Yes & $4(4,8)$ \\
\hline \multicolumn{2}{|l|}{ Breastfeeding, n (\%) } \\
\hline - No & $5(6,0)$ \\
\hline - Yes & $79(94,0)$ \\
\hline \multicolumn{2}{|l|}{ Method of Delivery, n (\%) } \\
\hline - Vacuum Extraction & $2(2,4)$ \\
\hline - Caesarean Section & $12(14,3)$ \\
\hline - Spontaneous & $70(83,3)$ \\
\hline \multicolumn{2}{|l|}{ Assistant of Delivery, n (\%) } \\
\hline - Midwife & $64(76,2)$ \\
\hline - General Physician & $10(11,9)$ \\
\hline - Obstetrician & $9(10,7)$ \\
\hline Traditional (Paraji) & $1(1,2)$ \\
\hline \multicolumn{2}{|l|}{ Compliance } \\
\hline - No & $2(2,4)$ \\
\hline - Yes & $82(97,6)$ \\
\hline
\end{tabular}

Annotation: n=frequency, \% percentage.
Based on Table 1, majority of subjects with HIVE lived outside Bandung (64,9\%) with statistical significance compared to NHIVE group ( $p$ value $=0.006$ ). Majority of the subjects were born spontaneously $(83,3 \%)$ and assisted by midwife $(76,2 \%)$. In both HIVE and NHIVE groups, most of the mothers were not given ARV during pregnancy and still breastfed their children. There was only 1 subject in HIVE group whose mother given ARV during pregnancy. All subject in both group were found to be compliant to the ARV therapy.

\subsection{Risk Factor of HIVE}

Table 2. Association of Risk Factor (Numeric) and Classification HIVE and NHIVE

\begin{tabular}{cccc}
\hline & HIVE & NHIVE & P \\
$\mathrm{n}=37$ & $24(6-96)$ & $36(2-96)$ & $\mathbf{0 , 0 2 4} *$ \\
& & 0 alue \\
\hline Age at diagnosis & $1(0-48)$ & $0(0-48)$ & $\mathbf{0 , 0 4 9 *}$ \\
$\begin{array}{c}\text { Time from diagnosis to } \\
\text { initiation of ARV }\end{array}$ & $48(9-144)$ & $60(4-144)$ & $\mathbf{0 , 0 4 8} *$ \\
Duration of Therapy & $17,9(0,0-41,0)$ & $16,0(1,0-33,0)$ & 0,435 \\
CD4 (\%) & $527(2-3568)$ & $515(15-2569)$ & 0,329 \\
CD4 (count) & &
\end{tabular}

Annotation: Analyzed with Mann Whitney, *significant $\mathrm{p}<0,05$.

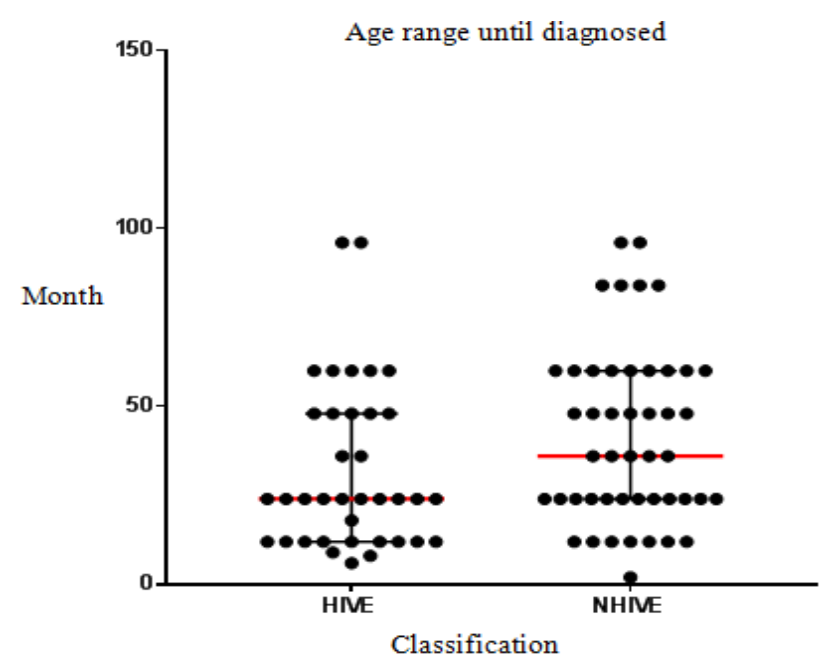

Figure 1. Scatter Distribution Age at Diagnosis of HIV

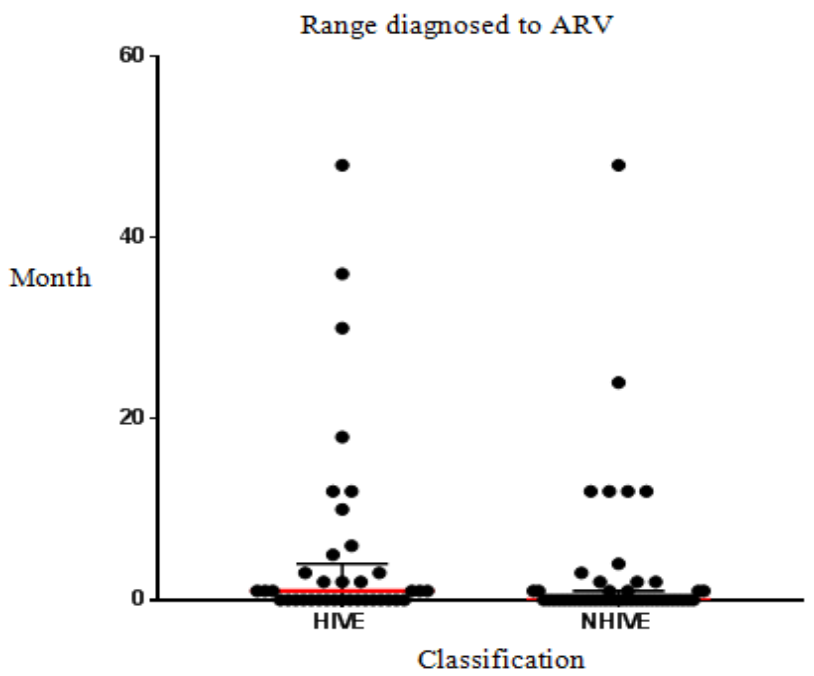

Figure 2. Scatter Distribution Time Initiation of ARV From HIV Diagnosis 


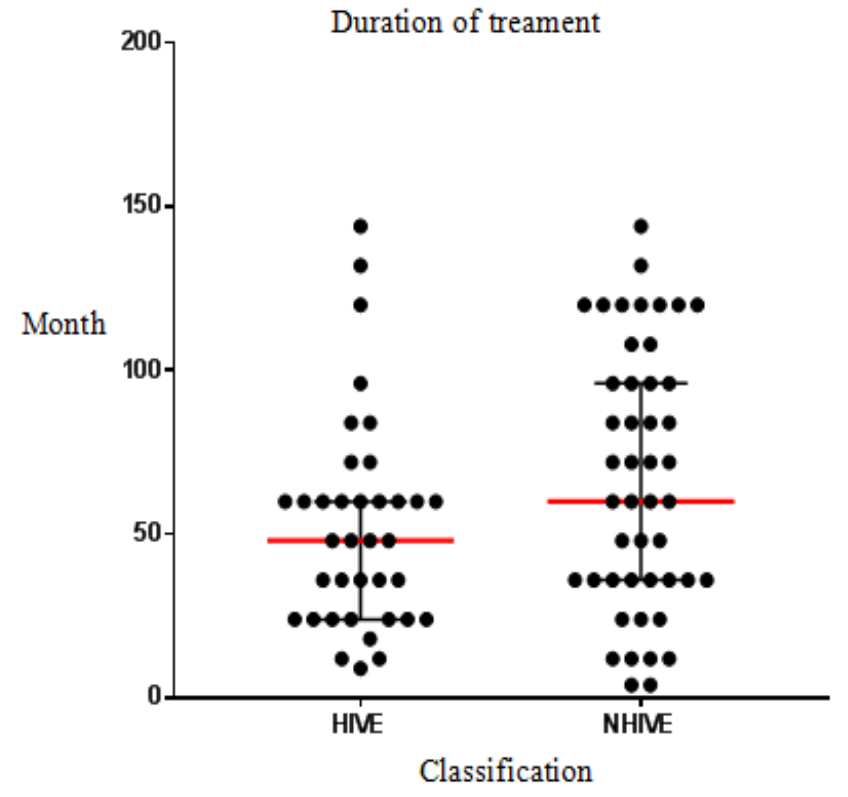

Figure 3. Scatter Distribution Duration of Therapy in HIVE and NHIVE Groups

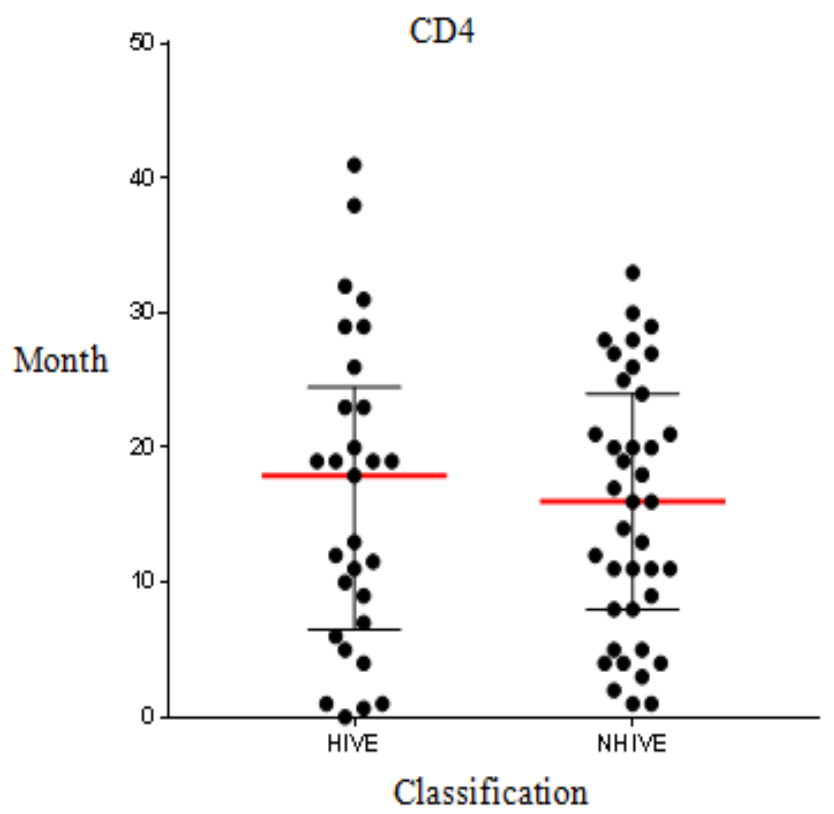

Figure 4. Scatter Distribution CD4 Percentage At Diagnosis in HIVE and NHIVE Groups

Mann-Whitney analysis showed children in NHIVE is significantly older at diagnosis than children in HIVE ( $p$ value $=0.024)$. Patient who received ARV for more than 1 month after diagnosis of HIV were found significantly to have more HIVE ( $p$ value $=0.049$ ). Subjects with more than 5 years of ARV therapy were significantly more in NHIVE group compared to HIVE group ( $p$ value $=0.048)$. There was no statistically significant difference CD4 percentage in both groups.

Chi square and fisher exact analysis showed that significant risk factors to HIVE were age at diagnosis, time from diagnosis to iniation of $\mathrm{ARV}$ and duration of therapy. Moreover, there were no statistically significance of stadium HIV at diagnosis and level of immunity between two groups.
Table 3. Association Risk Factor and Classification HIVE and NHIVE

\begin{tabular}{|c|c|c|c|}
\hline & $\begin{array}{c}\text { HIVE } \\
\mathbf{n}=37\end{array}$ & $\begin{array}{c}\text { NHIVE } \\
n=47\end{array}$ & $P$ value \\
\hline \multicolumn{4}{|c|}{ Age at diagnosis, n (\%) } \\
\hline$-\leq 2$ year & $23(62.2)$ & $20(42,6)$ & \multirow{2}{*}{$0,037^{\mathrm{a}} *$} \\
\hline - >2 year & $14(37,8)$ & $27(57,4)$ & \\
\hline \multicolumn{4}{|c|}{$\begin{array}{l}\text { Time from diagnosis to } \\
\text { initiation of ARV }\end{array}$} \\
\hline - 0 month & $17(45,9)$ & $30(63,8)$ & \multirow{2}{*}{$0,050^{a *}$} \\
\hline$-\geq 1$ month & $20(54,1)$ & $17(36,2)$ & \\
\hline \multicolumn{4}{|c|}{ Duration of therapy } \\
\hline$-\leq 5$ years & $29(78,4)$ & $24(51,1)$ & \multirow{2}{*}{$0,005^{a} *$} \\
\hline - >5 years & $8(21,6)$ & $23(48,9)$ & \\
\hline \multicolumn{4}{|l|}{ Stadium } \\
\hline-1 & $1(2,7)$ & $2(4,3)$ & \multirow{4}{*}{$0,446^{\mathrm{a}}$} \\
\hline-2 & $1(2,7)$ & $5(10,6)$ & \\
\hline-3 & $20(54,1)$ & $26(55,3)$ & \\
\hline-4 & $15(40,5)$ & $14(29,8)$ & \\
\hline \multicolumn{4}{|c|}{ Level of Immunity } \\
\hline - Severe & $17(45,9)$ & $18(38,3)$ & \multirow{4}{*}{$0,788^{\mathrm{a}}$} \\
\hline - Moderate & $3(8,1)$ & $6(12,8)$ & \\
\hline - Mild & $5(13,5)$ & $5(10,6)$ & \\
\hline - None & $12(32,4)$ & $18(38,3)$ & \\
\hline \multicolumn{4}{|l|}{ Compliance } \\
\hline - No & $2(5,4)$ & $0(0,0)$ & \multirow{2}{*}{$0,191^{\mathrm{b}}$} \\
\hline - Yes & $35(94,6)$ & $47(100,0)$ & \\
\hline
\end{tabular}

Annotation: Analyzed with ${ }^{\mathrm{a}}$ Uji Chi Square, ${ }^{\mathrm{b}}$ Fisher Exact *significant $\mathrm{p}<0,05$.

Table 4. Multivariat Logistic Regression Analysis

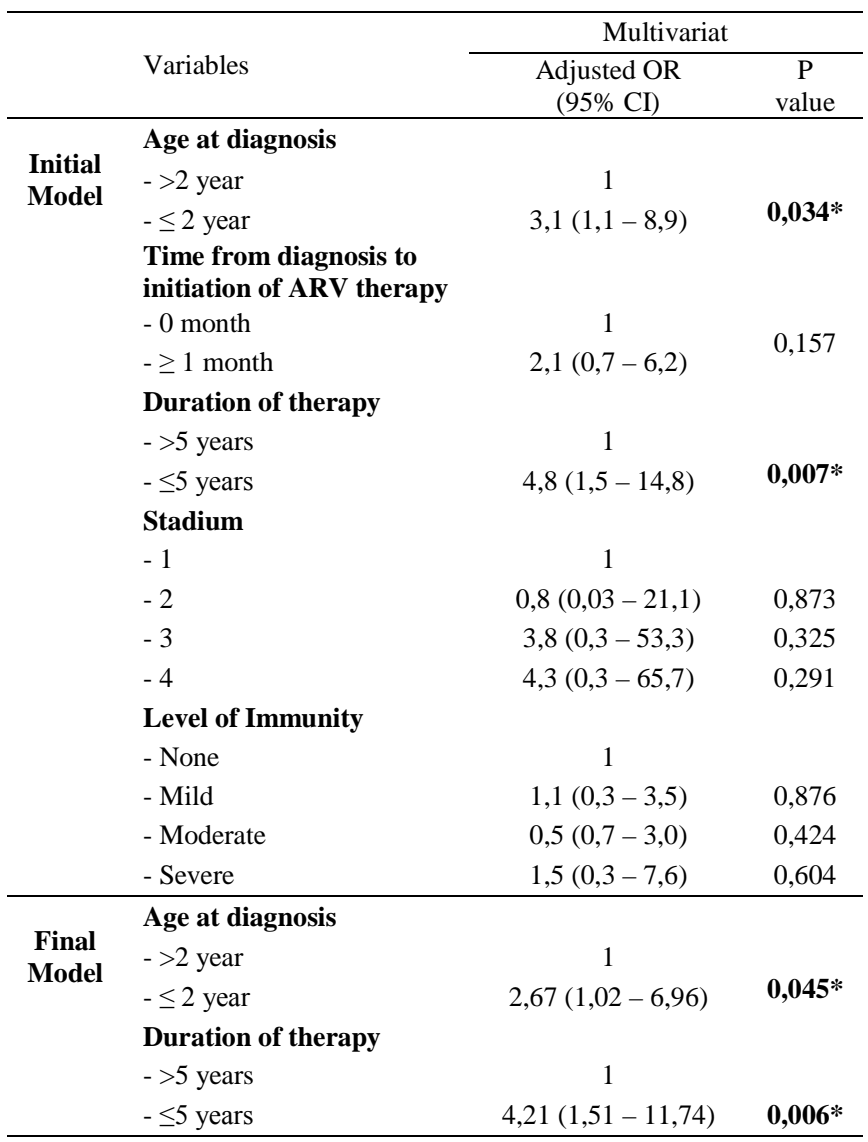

Dependent Variabel: HIVE,

Abbrevations: OR=Odds Ratio, CI=Confidence Interval, *significant $\mathrm{p}<0,05$. 
In multivariat logistic regression analysis, significant risk factor for HIVE are age at diagnosis ( $p$ value $=0.034)$ and duration of therapy ( $p$ value $=0.007$ ). There was a trend increasing risk of HIVE with increasing stadium HIV at time of diagnosis, however it was not statistically significant. There was also same trend for level of immunity at the time of diagnosis which is not statistically significant.

Table 5. Logistic Regression Equation Model

\begin{tabular}{lccc}
\hline & Coefficient $\beta$ & SE & P value \\
\hline Constant & $-1,621$ & 0,334 & $\mathbf{0 , 0 0 2 *}$ \\
Age at Diagnosis $(\leq \mathbf{2}$ Year) & 0,982 & 0,489 & $\mathbf{0 , 0 4 5 ^ { * }}$ \\
Duration of Therapy $(\leq \mathbf{5}$ Years) & 1,437 & 0,524 & $\mathbf{0 , 0 0 6 *}$ \\
\hline
\end{tabular}

Dependent Variable : HIVE.

Based on result of logistic regression analysis, regression model equation was obtained as follow:

$$
\mathrm{P}(\mathrm{y})=\frac{1}{1+\mathrm{e}^{-(\mathrm{y})}}=\frac{1}{1+\mathrm{e}^{-\left(-1,621+0,982 \mathrm{X}_{1}+1,437 \mathrm{X}_{2}\right)}} .
$$

Table 6. Possibility of HIVE Based on Logistic Regression Equation Model

\begin{tabular}{ccc}
\hline $\begin{array}{c}\mathbf{X}_{\mathbf{1}} \\
\text { Age at Diagnosis ( } \mathbf{2} \text { Y Year) }\end{array}$ & $\begin{array}{c}\mathbf{X}_{\mathbf{2}} \\
\text { Duration of Therapy } \\
(\leq \mathbf{5} \text { Years })\end{array}$ & $\mathbf{P}(\mathbf{y})$ \\
\hline 1 & 1 & 0.69 \\
0 & 1 & 0.45 \\
1 & 0 & 0.35 \\
0 & 0 & 0.16 \\
\hline
\end{tabular}

Annotation: $1=$ yes, $0=$ no.

The table above showed a patient who diagnosed at age $\leq 2$ year with duration of therapy $\leq 5$ years would have very high possibility of HIVE (69\%). A patient who diagnosed at age $\leq 2$ year but with duration of therapy $>5$ years, the possibility occurence of HIVE decreased into 35\%. A patient who diagnosed at age $>2$ year with duration of therapy $\leq 5$ years, the possibility occurence of HIVE was $45 \%$. And a patient who diagnosed at age $>2$ year with duration of therapy $>5$ years, the possibility occurence of HIVE was only $16 \%$. These comparisons showed that duration of therapy have important role in reducing possibility occurence of HIVE.

\section{Discussion}

\subsection{Incidence of HIVE}

This study showed the incidence of encephalopathy in children diagnosed with HIV was 37 patients (44\%). This is higher than study by Hamid etc in Malaysia who reported the incidence was $18,2 \%$. It may be caused by the fact Malaysian government have been implemented PMTCT program since 1998, earlier than Indonesian government in 2004. ${ }^{20}$ Maternal infected with HIV is given zidovudine during antenatal which is continued for 6 weeks for the offspring. Moreover, administration ARV in combination of 3 drugs have been implemented since 1998. Admiistration ARV to the infected pregnant woman and ARV combination to the children resulted to lower incidence HIVE in Malaysia. [20]

Incidence of HIVE in several studies are reported ranging $8-50 \%$. [20] A study in South Africa reported incidence of HIV was $2-60 \%$. [8,9] Administration of ARV to the HIV patient could decrease insidence of HIVE. Early administration of ARV in United States was reported to be successful in decreasing incidence of HIVE to only $2 \%$. [17] This study showed that incidence of HIVE was still high despite the subjects were given ARV. That finding can be caused by diagnosis delay of HIV in children thus resulting in delay of ARV administration. $\mathrm{HIV}$ is able to infect central nervous system very early which is at 6 days. ${ }^{13}$ Delay of ARV administration might cause persistent replication of HIV in central nervous system resulting in damage of white matter region. [12]

\subsection{Subject Characteristic}

The mean age of subjects with HIV was 71 months (range 20 - 153). Incidence of HIVE was lower in older subject. That may be caused by longer duration of ARV administration in such patients. ARV administration for more than 5 years was reported to decrease risk of HIVE about $80 \%$. [42] In group of NHIVE, the youngest subject was 2 months who needed long term observation to prevent occurence of HIVE.

Majority subjects who had HIVE came from outside of Bandung. Dr Hasan Sadikin General Hospital Bandung is the tertiary referral hospital in West Java so many difficult cases from accross province will be sent to this hospital. However, there are some hospitals in West Java who is able to manage HIV cases in children.

Indonesian government has been developing PMTCT program since 2004, but majority of infected pregnant woman who came to Teratai Clinic had no ARV therapy during pregnancy. This was because mother usually found HIV infection status after her children diagnosed by the attending physician. Most of subjects were even born spontaneously and breastfed since birth. PMTCT programs are including administration of ARV to the infected pregnant woman, caesarean delivery, no breastfeeding to the baby and ARV prophylaxis (zidovudine) for the baby for 6 weeks. Implementation of PMCTS programs were expected to reduce transplacental transmission by less than 1\%. [10]

PMTCT program does not include HIV examination in the newborn. For infant less than 18 months, virological examination can be done to evaluate HIV status. However that examination is often not feasible due to expensive price and not covered by national program. If HIV virological examination was not avaiblable, children should be observed regularly for signs and/or symptoms of HIV. Presumptive diagnosis of HIV in children less than 18 months is based on presence of minimal 1 criteria as follow PCP, meningitis, cryptococcus, esophageal candidiasis, toxoplasmosis, unresponsive severe malnutrition to standard management or presence of 2 symptoms as follow oral thrush, severe pneumonia, severe sepsis, maternal death due to HIV or advanced HIV disease in maternal, CD $4<20 \%$. The youngest subject diagnosed with HIV infection in this study was 2 months while the oldest was 96 months. HIV diagnosis in children 
more than 18 months is based on HIV antibody examination. [32]

\subsection{Risk Factor of HIVE}

\subsubsection{Level of Immunodeficiency}

This study showed worsening of immunodeficiency were not significantly related to occurence of HIVE. Another study reported worsening immunodeficiency was related to increasing incidence of HIVE. Patel etc. [17] found that CD $4<15 \%$ or low immunity level increased possibility occurence of HIVE up to 8 times. Hamid etc. [20] also found low CD4 as risk factor of HIVE.

Lowest CD4 in HIVE and NHIVE group of this study was $0 \%$ (range $0-41 \%$ ) and $1 \%$ (range $1-33 \%$ ) consecutively. About 45,9\% subjects in HIVE group had severe immunodeficiency since CD4 is the main target of HIV-1. However that finding is not statistically significant.

\subsubsection{HIV Stadium}

HIV stadium according to WHO is established at first visit of the subjects. This study showed trend of increasing incidence of HIVE with increasing stadium of HIV. Subject with stadium 4 of HIV had increased risk of HIVE, but not statistically significant. The insignificance may be related to research design of this study which was crosssectional. Hamid etc. ${ }^{20}$ also found that majority of patients with HIVE had higher HIV stadium (3 or 4). Majority of the subjects were brought to hospital because severe manifestation and no improvement with therapy in previous health facilities.

\subsubsection{Age At Diagnosis of HIV}

Multivariat logistic regression analysis showed that significant risk factor for HIVE was age at diagnosis and duration of therapy. Patients diagnosed at age $>2$ years were found more in NHIVE group. Subjects in NHIVE group might have lower HIV stadium and longer duration of ARV therapy.

Patients diagnosed at age $\leq 2$ years had higher incidence of HIVE. It was depending to HIV stadium at the diagnosis. Younger subject was reported to have more severe progressivity of the disease. $[8,9,25]$ A study by Patel K etc. [17] also reported age as risk factor of HIVE. Children diagnosed at age less than 1 year had increased risk of HIVE for about 3 times.

\subsubsection{ARV Administration}

HIV treatment in children should be started at age less than $10-12$ weeks and continued for lifetime. [13,26] ARV is reported effective in reducing viral load of HIV-1 and brain inflammation. [33] Life expectancy of untreated children with HIV was only less than 24 months. [16] Routine administration of ARV in USA and Europe has reduced incidence of HIVE from $30 \%$ to only $2 \%$. [26] Early administration of ARV will reduce likelihood of HIVE. [13,26] Brain imaging study reported white matter changes have been formed since beginning of life. Another study also reported ARV administration at age 7 - 8 weeks was too late to prevent HIV-1 entry to central nervous system. [40] Early administration of ARV could prevent worsening white matter lesion and widening brain sulci thus improving long term outcome of the children. [40]

After diagnosed as HIV, ARV administration will begin as indication. 32 - 49\% patients diagnosed as HIV in South Africa were not given ARV in 2011 and 2014. [7] Delay of ARV administration causes continuing multiplication of HIV especially in central nervous system thus increasing risk occurence of HIVE. Van Arnhem LA etc. [42] found early administration of ARV was really important to prevent widening lesion in the white matter.

Pulmonary tuberculosis (TB) often occurs together with HIV. Patient with HIV who also diagnosed as pulmonary TB need to be given anti tuberculosis drugs for minimal 2 weeks and continued by administration of ARV. Oppurtunistic infection in patient with HIV indicates severe immunodeficiency. The criteria for administering ARV on immunological status also often become delay in HIVE prevention. [43]

Most of subjects in this study received ARV right after establishment of diagnosis. Patients who received ARV more than 1 month after diagnosis had increased risk occurence of HIVE.

Age at adminstration of ARV is reported to be an important predictor neurological outcome in children. [16] If ARV was administered in early infancy, the possibility penetration of HIV-1 into central nervous system would be decreased into less than 2\%. [16] Smith L etc. [16] reported the condition of encephalopathy has become static since the use of antiretroviral drugs for 6 months.

\subsection{Duration of Therapy}

The patients were given 3 types from 2 different classifications of ARV. ARV with capability to accross blood brain barrier should be the drug of choice in children since it was reported to decrease incidence of HIVE for $41 \%$. [17] With potential long laten phase (10 years), HIVE could occur at any time. A study in India reported administration of ARV for 1 year resulted in improvent of children with HIVE. [18]

Adminstration regimen of $\mathrm{ARV}$ is reported to reduce incidence of HIVE for 50\%. [17] Duration of therapy has important role in reducing risk of HIVE in children. A study in Cape Town reported shorter ARV administration was found more in HIVE patient with improvement of spasticity in both legs. [8]

Administration of therapy for more than 5 years will improve quality life of children. In this study, there were more subjects in NHIVE group with longer duration of therapy. That finding is consistent to other studies which reported longer duration of therapy reduced risk occurence of HIVE. [26] Van Arnhem etc. [42] reported long term administration of ARV did not repair lesion in white matter. Structural abnormalities based on MRI which may be improved by administration of ARV were ventricle enlargement and widening brain sulci. [42]

Compliance to ARV treatment is very important. Abnormality in white matter is reported more marked in less compliant patients. [40] Many patients were orphan or living with the guardian. Good education from medical staff is very important in supporting compliance for the ARV therapy. Despite good compliance of the patients in this study, the incidence of HIVE was still high. This 
phenomenon might caused by high HIV stadium and immunodeficiency status at diagnosis of HIV.

\subsection{Limitation}

The limitation of this study is the cross-sectional design thus there was no observation for developmental of the children. This study had no neurocognitive examination which important to detect neurocognitive problems in children with HIV.

\section{Conclusions}

\subsection{General Conclusions}

Based on the results, the general conclusions of this study are as follow:

1. Low level of immunodeficiency at diagnosis of HIV is not risk factor of HIVE

2. High stadium of HIV is not risk factor of HIVE

3. Early age at diagnosis of $\operatorname{HIV}(\leq 2$ year $)$ is associated with higher risk of HIVE

4. Delay administration of ARV is not risk factor of HIVE

5. Longer duration therapy of ARV ( $>5$ years) is associated with decreasing risk of HIVE

\subsection{Specific Conclusion}

Based on discussion of the results, the specific conclusion of this study is duration therapy of ARV is the most important risk factor in reducing incidence of HIVE. The longer duration therapy of ARV ( $>5$ years) is associated with decreased possibility occurence of HIVE (16\%).

\section{References}

[1] Bale JF. Viral infection.of the nervous system. Dalam: Swaiman KF, Ashwal S, Ferriero DM, Schor NF,editor. Pediatric Neurology. Edisi ke 5. China:Elsevier Saunders. 2012.h. 1262-90.

[2] Yogev R, Chadwick EG.Acquired Immunodeficiency Syndrome (Human Immunodeficiency Virus). Dalam: Kliegman R, Stanton BM, St Geme III JW, Schor NF, Behrman RE, penyunting. Nelson Textbook of Pediatirics, Edisi ke-20. Philadelphia: Elsevier; 2016. hlm. 1645-66.

[3] World Health Organization. HIV/AIDS. Terdapat pada: http://www.who.int/hiv/en. [Diunduh tanggal 5 Juli 2016].

[4] UNAIDS. Global AIDS Up To Date. 2016.

[5] Kementerian Kesehatan Indonesia. Profil Kesehatan Indonesia 2015. 2016.

[6] Rahmalia A, Wisaksana R, Meijerink H, Indrati AR, Alisjahbana B, Roeleveld N,dkk. Women with HIV in Indonesia: are they bridging a concentrated epidemic to the wider community? BMC Res Notes. 2015; 8: 1-8.

[7] Mann TN, Donald KR, Barbara laughton, Lamberts RP, Langerak NG. HIV encephalopathy with bilateral lower limb spasticity: upper limb motor function and level of activity and participation. Dev Med Child Neurol. 2016: 1-5.

[8] Mann TN, Donald KR, Walker KG, Langerak NG. Resolved lower limb muscle tone abnormalities in children with HIV encephalopathy receiving standard antiretroviral therapy.AIDS Res Ther. 2015; 12: 43: 1-5.

[9] Donald KA, Walker KG, Kilborn T, Carrara H, Langerak NG, Eley B, dkk. HIV Encephalopathy: Pediatric Case Series
Description And Insights From The Clinic Coalface. AIDS Res Ther.2015; 12: 1-10.

[10] Phanuphak N, Phanuphak P. History of the prevention of mother to child transmission of HIV in Thailand. Journal of virus eradication 2016; 2: 107-9.

[11] Donald KA, Walker K, Riordan G, Govender R, Wilmshurst J. The neurological complication of HIV/AIDS in childhood. CMEJ. 2012; 30(1): 1-7.

[12] Miura Y, Koyanagi Y. HIV encephalopathy. JMAJ. 2006; 49: 212-8.

[13] Cotton MF, Rabie H. Impact of earlier combination antiretroviral therapy on outcomes in children. Wolter Kluwer Health. 2014; 9: 1-6.

[14] Tardieu M, Chenadec JL, Persoz A, Meyer L, Blanche S, Mayaux MJ. HIV-1 related encephalopathy in infants compared with children and adults. Neurology. 2000; 54: 1089-95.

[15] Robertson K, Liner J, Meeker RB. Antiretroviral neurotoxicity. J Neurovirol. 2012; 18(5): 388-99.

[16] Smith L, Adnams C, Eley B. Neurological And Neurocognitive Function Of HIV-Infected Children Commenced On Antiretroviral Therapy. SAJCH. 2008; 2: 108-3.

[17] Patel K, Ming Xue, Williams PL, Robertson KR, Oleske JM, Seage GR, dkk. Impact Of HAART And CNS-Penetrating Antiretroviral Regimens On HIV Encephalopathy Among Perinatally Infected Children And Adolescents. NIH. 2009; 23: 1893-1901.

[18] Kundu CK, Samanta M, Bhattacharyya S. HIV encephalopathy masquerading as infantile stroke syndrome:Treatment after antiretroviral did wonders. JPIDS. 2011; 6: 59-62.

[19] Kurniati N. Pedoman penerapan terapi HIV pada anak. Kementerian Kesehatan Republik Indonesia. 2014

[20] Hamid MZA, Aziz NA, Zulfifli ZS, Norlijah O, Azhar RK. Clinical Features And Risk Factors For HIV Encephalopathy in Children. Southesast Asian J Trop Med Pulic Health. 2008; 39(2): 266-72.

[21] Walker SY, Pierre RB, Christie CD, Chang SM. Neurocognitive function in HIV-positive children in a developing country. Int J Infect Dis. 2013; 17: 862-7.

[22] Pearson DA, McGrath NM, Nozyce M, Nichols SL, Raskino C, Brouwers P,dkk. Predicting HIV disease progression in children using measures of neuropsychological and neurological functioning. Pediatrics. 2000; 106(6): 1-10.

[23] Chase C, Ware J, Hittelman J, Blasini I,Smith R, Llorente A, dkk Early cognitive and motor development among infants born to woman infected with human immunodeficiency virus.women and infatns transmission study group. Pediatrics. 2000; 106(2): E25.

[24] Sherr L, Croome N, Castaneda K, Bradshaw K, Romero RH. Developmental challenges in HIV infected children-an update systematic review. Children and Youth Services Reviews 2014; 45 74-89.

[25] Van Rie A, Harrington PR, Dow A, Robertson K. Neurologic and Neurodevelopmental Manifestations Of Pediatric HIV/AIDS: a global perspective. European Journal of Pediatric Neurologi. 2007; 11: $1-9$.

[26] Le Doare K, Newel M. Neurodevelopment In Children Born To Hiv-Infected Mothers By Infection And Treatment Status. Pediatrics. 2012; 130: e1326-44.

[27] Muhaimin T. Impact of HIV/AIDS in the family on children's quality life. Med J Indones. 2010; 19: 280-6.

[28] Nwaneri DU. HIV/AIDS:Complications and challenges; the Nigerian experience in pediatric practice.Benin Journal of Postgraduate Medicinee. 2007; 9(1): 58-63

[29] George R, Andronikou S, Plessis Jd, Plessis A-Md, Toorn RV, Maydell A. Central nervous system manifestations of HIV infection in children. Pediatr Radiol. 2009; 39: 575-85.

[30] Shah SR, Tullu MS, Kamat JR. Clinical Profile of Pediatric HIV Infection from India. Archives of Medical Research. 2004; 36 : 24-31.

[31] Burchett SK, Pizzo PA. HIV Infection in Infants, Children, and Adolescents. Pediatrics in Review. 2003; 6: 186-94.

[32] Kementerian Kesehatan Republik Indonesia. Dalam: Pedoman Penerapan Terapi HIV Pada Anak. Nia K, editor. 2014.

[33] Blokhuis C, Kootstra NA, Caan MWA, Pajkrt D. Neurodevelopmental Delay In Pediatric Hiv/Aids:Current Perspectives. Neurobehavioural HIV Medicine. 2016; 7: 1-13. 
[34] Chu C, Selwyn PA. Complication or HIV infection: a systems-based approach. Am Fam Physician. 2011; 83(4): 395-406.

[35] Calles NR, Evan D, Terlonge D. Pathophysiology of the Human Immunodeficiency Virus. HIV curriculum for the health professional. 2010: 7-14.

[36] Lowenthal ED, Cruz N,Yin D. Neurologic And Psychiatric Manifestations Of Pediatric Hiv Infection. HIV curriculum for the health professional. 2010: 194-95.

[37] Elbirt D, Guri KM, Rosenberg SB, Gill H, Attali M, Asher I. HIVAssociated Neurocognitive Disorders (HAND). IMAJ. 2015; 17: 54-9.

[38] Tahan TT, Bruck I, Burger M, Cruz CR. Neurological profile and neurodevelopment of 88 children infected with HIV and 84 seroconverted children followed from 1995 to 2001. The Brazilian Journal of Infectious Diseases. 2006; 10(5): 322-26.

[39] Melvin D, Biggs R, Coomer A, Krechevsky D.Monitoring
Neurodevelopmental And Neurocognitive Outcomes In The Uk Paediatric Hiv Cohort. CHIVA guidelines. 2012: 1-15.

[40] Van Ackermann C, Andronikou S, Laughton B, Kidd M, Dobbels E, Innes S, Toorn R, Cotton M. White Matter Signal Abnormalities In Children With Suspected HIV-Related Neurologic Disease On Early Combination Antiretroviral Therapy. Pediatr Infect Dis J. 2014; 33: e207-12.

[41] Tardie M, Brunelle F, Raybaud C, Ball W, Barret B, Pautard B,dkk. Cerebral MR Imaging in Uninfected Children Born to HIV-Seropositive Mothers and Perinatally Exposed to Zidovudine. AJNR 2005; 26: 695-701.

[42] Van Arnhem LA, Bunders MJ, Scherpbier HJ, Majoie CB, Reneman L, Frinking O, dkk. Neurologic Abnormalities in HIV-1 Infected Children in the Era of Combination Antiretroviral Therapy. Plos one 2013; 8(5): 1-6.

[43] Sopiyudin M. Besar Sampel Dalam Penelitian Kedokteran dan Kesehatan. Edisi 4. Epidemiologi Indonesia.2016.

C The Author(s) 2019. This article is an open access article distributed under the terms and conditions of the Creative Commons Attribution (CC BY) license (http://creativecommons.org/licenses/by/4.0/). 